\title{
Choristoneura rosaceana (Harris) AND Pandemis pyrusana Kearfott (LEPIDOPTERA: TORTRICIDAE) MALE CONTROL IN WASHINGTON STATE (USA) APPLE ORCHARDS TREATED WITH DIFFERENT SOURCE DENSITIES OF SEVERAL ATTRACTICIDE FORMULATIONS
}

\author{
Control de machos de Choristoneura rosaceana (Harris) y Pandemis pyrusana Kearfott \\ (Lepidoptera: Tortricidae) en huertos de manzanos del Estado de Washington (EE.UU.) \\ tratados con diferentes densidades de varias formulaciones atracticidas
}

\author{
Tomislav Curkovic ${ }^{1}$, Jay F. Brunner ${ }^{2}$
}

\begin{abstract}
A B S T R A C T
This is the first report on attracticides loaded with 1.6 or $16 \%$ pheromone, with or without $6 \%$ permethrin, tested for Choristoneura rosaceana (Harris) and Pandemis pyrusana Kearfott male control. Different densities of attracticide sources (750-3,600 droplets $\mathrm{ha}^{-1}$ ) homogeneously applied on the canopy were compared in apple (Malus pumila Mill.) orchards. Before attracticide application, no differences in male captures using pheromone baited trap were observed. Afterwards, a significant reduction of captures occurred along with the increasing pheromone concentration, when larger density sources were used. The addition of permethrin into the attracticide formulation, however, did not significantly improve the reduction of males. Overall, these results suggest that mating disruption or other mechanism, instead of the killing effect attributed to attracticides, controlled males. It is suggested to test the attracticide formulation matrix reported as an alternative to the current ones used for mating disruption.
\end{abstract}

Key words: attracticides, Choristoneura rosaceana, Pandemis pyrusana, permethrin, pheromone concentration, point source density, mating disruption.

\section{R E S U M E N}

Este es el primer informe del control de machos de Choristoneura rosaceana (Harris) y Pandemis pyrusana Kearfott con atracticidas que contengan 1,6 ó $16 \%$ de feromona, con o sin permetrina al $6 \%$. Se compararon diferentes densidades de atracticidas (750-3.600 gotas ha-1), aplicadas homogéneamente en la copa de los manzanos (Malus pumila Mill.). Antes de los tratamientos no se observaron diferencias estadísticas en las capturas en trampas cebadas con feromona. Después de aplicar los tratamientos, se observó una reducción significativa en las capturas, al usar mayores concentraciones de feromona y mayores densidades de gotas por hectárea. La incorporación de permetrina en la formulación atracticida no mejoró su actividad en el control de machos. En general, los resultados sugieren que un efecto similar a la confusión de cópula, en lugar de un efecto letal atribuible al atracticida, o bien otro mecanismo, controló a los machos de estas especies. La matriz grasosa usada en la formulación atracticida se sugiere como una alternativa para ser probada respecto de las formulaciones actualmente usadas para confusión de cópula.

Palabras clave: atracticidas, Choristoneura rosaceana, Pandemis pyrusana, permetrina, concentración de feromona, densidad de fuentes, confusión de cópula.

\footnotetext{
${ }^{1}$ Universidad de Chile, Facultad Cs. Agronómicas, Casilla 1004, Santiago, Chile.

E-mail: tcurkovi@uchile.cl*Autor para correspondencia.

${ }^{2}$ Washington State University, Tree Fruit Research and Extension Center, Wenatchee, Washington 98801, USA.

E-mail: jfb@wsu.edu

Recibido: 15 de diciembre de 2005. Aceptado: 12 de mayo de 2006.
} 


\section{INTRODUCTION}

Sex pheromone loaded attracticide formulations have been reported for several Tortricidae, such as Cydia pomonella L. (Charmillot et al., 2000) and C. molesta (Busck) (Evenden and McLaughlin, 2005). The pheromone acts as a specific attractant, leading male moths from a distance to the source (Curkovic and Brunner, 2006). Attracticide formulations also include an insecticide and inert ingredients (Curkovic and Brunner, 2005). This pest control technique relies on point source applications which lower pesticide residues on fruits, and minimizes probabilities of pesticide resistance development (Krupke et al., 2002). However, their efficacy depends on the lethal contact of individuals (usually males) to the source (Curkovic and Brunner, 2005). To do so, the formulation must induce the regular courtship behavior in males of both species; this has already been reported to be compatible with the attracticide mode of action (Curkovic et al., 2006).

Attracticides are an alternative to conventional pesticides and reduce risks for applicators, the environment and beneficial arthropods (Curkovic and Brunner, 2003). Reding and Alston (1999) found low levels of $C$. pomonella damage at harvest in relatively small plots treated with attracticides under high pest pressure. However, subsequent larger field trials under high $C$. pomonella pressure did not provide a satisfactory control (Dr. Mark Reding, 1999. Utah State University, Logan, Utah, EE.UU., personal communication). Curkovic and Brunner (2003) reported that captures of $C$. pomonella males in traps were similar between an attracticide and mating disruption treatments and significantly lower than in a control. However, fruit injury at harvest did not show statistical differences among treatments, probably because fertilized females migrated into plots treated with pheromones from surrounding areas (Beers et al., 1993).

The objective of this study was to evaluate attracticides containing either 1.6 or $16 \%$ of the specific pheromone, with or without permethrin, using different source densities, to suppress males of Choristoneura rosaceana or Pandemis pyrusana populations, two increasing apple pests in the State of Washington, USA, under field conditions.

\section{MATERIALS AND METHODS}

The attracticide used was a grease formulation (Last $\mathrm{Call}^{\mathrm{TM}}$, IPM Technologies, Portland, Oregon, USA) including an ultraviolet stabilizer (over 70\%), a thickener and a sticker. Two batches of attracticide formulation were prepared. In the case of $C$. rosaceana, the attracticide was loaded with a mixture containing $95.5 \%$ of cis-11-tetradeca-1acetate (Z11-14Ac following the nomenclature used by Stevens, 1998), 2\% of trans-11-tetradeca-1acetate (E11-14Ac), 1.5\% of cis-11-tetradeca-1alcohol (Z11-14OH), and 1\% of cis-11-tetradeca1- aldehyde (Z11-14Al). This was based on the blend reported by Vakenti et al. (1988). In the case of $P$. pyrusana, the proportions of pheromone components in the attracticide were $94 \%$ of cis-11tetradeca-1- acetate (Z11-14Ac) and $6 \%$ of cis-9tetradeca-1- acetate (Z9-14Ac). The later blend was reported by Roelofs et al. (1977). Purities of pheromone components (all above 95\%) were provided by the manufacturer (Bedoukian Research Inc., Danbury, Connecticut, USA). The pheromone components for each species were added directly to the matrix to prepare mixtures containing either 1.6 or $16 \%$ of the pheromone blend (by weight), then mechanically stirred while in a warm-bath for $5 \mathrm{~min}$, and finally poured into a $250 \mathrm{~mL}$ bottle. The bottles include a dispenser that releases droplets of approximately $50 \mu \mathrm{L}$. Technical permethrin $(92 \%$ purity) (Valent Biosciences, Libertyville, Illinois, USA) was also added into the formulation up to $6 \%(\mathrm{w} / \mathrm{w})$, using the procedure described above. Batches without insecticide, but containing pheromones, were used as blank-attracticides in each species. All mixtures were stored at $0 \pm 1{ }^{\circ} \mathrm{C}$ and kept at $22 \pm 1{ }^{\circ} \mathrm{C}$ for $\sim 30 \mathrm{~min}$ before use.

Field trials were established in apple (Malus pumila Mill.) orchards cvs. Red Delicious (Winchester) and Fuji (Quincy), at Douglas County, Washington, USA. The orchards were infested with $C$. rosaceana and/or $P$. pyrusana and were not sprayed with insecticides during the season. The different attracticide treatments applied at each location are outlined in Table 1. Drops of attracticide were distributed evenly around the canopy of apple trees at a height of $1.5-2 \mathrm{~m}$. The attracticide was applied only once in each orchard. Delta traps (LPD type, Scenturion, Inc., Coupville, Washington, USA) were placed in the center of each replicate and there was at least $25 \mathrm{~m}$ between traps. 
Table 1. Orchards, target species, application dates, attracticide formulations and source densities tested in each field trial, 2002.

Cuadro 1. Huertos, especies plaga tratadas, fechas de aplicación, formulaciones atracticidas y densidades de fuentes evaluadas en cada ensayo de campo, 2002.

\begin{tabular}{|c|c|c|c|c|}
\hline $\begin{array}{l}\text { Orchard location and } \\
\text { species targeted }\end{array}$ & $\begin{array}{c}\text { Application } \\
\text { date }\end{array}$ & $\begin{array}{c}\text { Pheromone } \\
(\%)\end{array}$ & $\begin{array}{c}\text { Permethrin } \\
(\%)\end{array}$ & $\begin{array}{l}\text { Source density } \\
(\text { Droplets ha } \\
\end{array}$ \\
\hline \multicolumn{5}{|c|}{ Winchester, Washington, USA } \\
\hline Choristoneura rosaceana & Aug. $20^{\text {th }}$ & 1.6 vs. 16 & 0 vs. 6 & 1,200 vs. 3,600 \\
\hline Pandemis pyrusana & Aug. $21^{\text {st }}$ & 1.6 vs. 16 & 0 vs. 6 & 1,200 vs. 3,600 \\
\hline \multicolumn{5}{|l|}{ Quincy, Washington, USA } \\
\hline Choristoneura rosaceana & Sep. $5^{\text {th }}$ & 1.6 vs. 16 & 6 & 750 vs. 2,250 \\
\hline Pandemis pyrusana & Aug. $28^{\text {th }}$ & 1.6 vs. 16 & 6 & 1,000 vs. 3,000 \\
\hline
\end{tabular}

Traps were baited with regular lures (septa provided by IPM Technologies, $1 \mathrm{mg}$ pheromone each), loaded with the same specific pheromone blends mentioned above. Monitoring started a few days before the treatments were applied in the field, in order to demonstrate that a leafroller population was present at that time in those particular orchards. Traps were examined periodically (every 2-3 days), for approximately one month for counting moths, liner replacement and cleaning.

A randomized complete block design with three replicates (at least 0.1 ha each) was used. The impact of treatments on males was evaluated by recording capture of moths in traps. This variable is considered more appropriate than measurement of damages caused by larvae to test attracticides targeting adult males. Proportions of cumulative captures within blocks were arcsin square-root transformed, analyzed by ANOVA and Tukey test before and after applications for each orchard. SEM values are included with tables $(\mathrm{P}=0.05)$ (Zar, 1996).

\section{RESULTS AND DISCUSSION}

There was a similar trend among field trials for species C. rosaceana and P. pyrusana (Tables 2 to $5)$. The cumulative male captures before attracticide applications were relatively low and no statistical differences were observed between plots assigned to the different treatments. After applications, the captures in all attracticide treated plots (except 1.6\% pheromone with permethrin using 1,200 droplets $\mathrm{ha}^{-1}$, Table 2) were significantly lower than the untreated check.

Results demonstrated that the attracticide treatments reduced male abilities to find pheromone sources, in both species. Two reasons that seem most plausible to explain these results are: either the males were killed by contact with the attracticide or were inhibited from locating the trap because of some male disruption effect as described by Jones (1998). Both explanations are possible and were proposed previously to explain the results of attracticide treatments in other field studies, targeting other species (Miller et al., 1990; Downham et al., 1995; Krupke, 1999; Suckling and Brockerhoff, 1999; Charmillot et al., 2000).

Based on Curkovic and Brunner (2006), it is expected males to be strongly attracted to attracticide sources with the higher pheromone concentrations, that is, more males would be eliminated or at least removed from the reproductive population after contact with those attracticide formulations, as suggested by De Souza et al. (1992). However, the results reported here indicate that in all cases there were no statistical differences in favor of using a high concentration, $16 \%$ pheromone attracticide with or without insecticide, suggesting that the lethal agent was not necessary to affect moth populations. These data are in contrast to those reported by Suckling and Brockerhoff (1999), as they found significantly more Light Brown Apple [Epyphias postvittata (Walker)] (Lepidoptera: Tortricidae) moth males in traps placed in plots treated with caged attracticide sources, which did not allow source contact but did allow pheromone release (similar to the free-insecticide attracticide reported here), versus a treatment with regular attracticide that did allow direct contact.

This suggests that, if a contact with the source is allowed (equivalent to the insecticide loaded attracticide treatment), fewer males would be able to fly to traps, presumably because they would have been killed as observed in lab bioassays by Curkovic and Brunner (2005). However, in some experiments reported here (Table 2), there were significantly larger moth captures in the attracticide treatment that included the insecticide. Therefore, 
Table 2. Captures of Choristoneura rosaceana in traps between Aug. 17-19 (pretreatments) and between Aug. 20 Sep. 18 (post-treatments) in an apple orchard treated with different attracticide source densities (1,200 vs. 3,600 droplets $\left.\mathrm{ha}^{-1}\right)$, with and without permethrin $(6 \%$ vs. $0 \%)$, using two pheromone concentrations at the source (1.6 or 16\%), Winchester, Washington, USA.

Cuadro 2. Capturas de Choristoneura rosaceana entre el 17 y 19 de agosto (pretratamientos) y el 20 de agosto - 18 de septiembre (postratamientos) en un huerto de manzanos tratado con diferentes densidades de fuentes atracticidas (1.200 vs. 3.600 gotas ha $\left.{ }^{-1}\right)$, con y sin permetrina (6 vs. $\left.0 \%\right)$, usando dos concentraciones de feromona en la fuente (1,6 ó 16\%), Winchester, Washington, EE.UU.

\begin{tabular}{ccccc}
\hline $\begin{array}{c}\text { Pheromone } \\
(\%)\end{array}$ & $\begin{array}{c}\text { Permethrin } \\
(\%)\end{array}$ & $\begin{array}{c}\text { Source density } \\
\left.\text { (droplets ha }^{-1}\right)\end{array}$ & \multicolumn{2}{c}{ Average males/trap/day \pm SEM } \\
\hline 1.6 & 0 & 1,200 & $0.7 \pm 0.34 \mathrm{a}$ & $0.04 \pm 0.000 \mathrm{~b}$ \\
1.6 & 0 & 3,600 & $1.0 \pm 0.43 \mathrm{a}$ & $0.05 \pm 0.002 \mathrm{~b}$ \\
1.6 & 6 & 1,200 & $0.7 \pm 0.34 \mathrm{a}$ & $0.06 \pm 0.006 \mathrm{a}$ \\
1.6 & 6 & 3,600 & $0.7 \pm 0.34 \mathrm{a}$ & $0.02 \pm 0.001 \mathrm{~b}$ \\
16 & 0 & 1,200 & $0.5 \pm 0.14 \mathrm{a}$ & $0.00 \pm 0.000 \mathrm{~b}$ \\
16 & 0 & 3,600 & $0.5 \pm 0.14 \mathrm{a}$ & $0.00 \pm 0.000 \mathrm{~b}$ \\
16 & 6 & 1,200 & $0.7 \pm 0.34 \mathrm{a}$ & $0.01 \pm 0.000 \mathrm{~b}$ \\
16 & 6 & 3,600 & $0.8 \pm 0.67 \mathrm{a}$ & $0.00 \pm 0.000 \mathrm{~b}$ \\
0 & 0 & 0 & $1.0 \pm 1.01 \mathrm{a}$ & $0.51 \pm 0.155 \mathrm{a}$ \\
\hline
\end{tabular}

Before attracticide applications, there were no significant differences in male captures in this orchard, $\mathrm{F}=1.74 ; \mathrm{df}=8.16 ; \mathrm{p}>0.1$. However, significant differences were observed after treatments, $\mathrm{F}=24.46$; $\mathrm{df}=8.16 ; \mathrm{p}<0.001$.

Table 3. Captures of Pandemis pyrusana in traps between Aug. 17-20 (period pre-treatments) and between Aug. 21-Sep. 18 (post-treatments) in apple orchard plots treated with different attracticide source densities (1,200 vs. 3,600 droplets $\left.\mathrm{ha}^{-1}\right)$, with and without permethrin (6 vs. $0 \%$ ), using two pheromone concentrations at the source (1.6 or 16\%), Winchester, Washington, USA.

Cuadro 3. Capturas de Pandemis pyrusana entre el 17-20 de agosto (pretratamientos) y el 21 de agosto-18 de septiembre (postratamientos) en un huerto de manzanos tratado con diferentes densidades de fuentes atracticidas (1.200 vs. 3.600 gotas ha-1), con y sin permetrina (6 vs. 0\%), usando dos concentraciones de feromona en la fuente (1,6 ó 16\%), Winchester, Washington, EE.UU.

\begin{tabular}{ccccc}
\hline $\begin{array}{c}\text { Pheromone } \\
(\%)\end{array}$ & $\begin{array}{c}\text { Permethrin } \\
\mathbf{( \% )}\end{array}$ & $\begin{array}{c}\text { Source density } \\
\left.\text { (droplets ha }^{-1}\right)\end{array}$ & \multicolumn{2}{c}{ Average males/trap/day \pm SEM } \\
\hline 1.6 & 0 & 1,200 & $0.50 \pm 0.14 \mathrm{a}$ & Post \\
1.6 & 0 & 3,600 & $0.33 \pm 0.19 \mathrm{a}$ & $0.00 \pm 0.00$ \\
1.6 & 6 & 1,200 & $0.50 \pm 0.14 \mathrm{a}$ & $0.00 \pm 0.00$ \\
1.6 & 6 & 3,600 & $0.33 \pm 0.05 \mathrm{a}$ & $0.00 \pm 0.00$ \\
16 & 0 & 1,200 & $0.67 \pm 0.77 \mathrm{a}$ & $0.00 \pm 0.00$ \\
16 & 0 & 3,600 & $1.17 \pm 0.91 \mathrm{a}$ & $0.00 \pm 0.00$ \\
16 & 6 & 1,200 & $0.50 \pm 0.43 \mathrm{a}$ & $0.00 \pm 0.00$ \\
16 & 6 & 3,600 & $0.50 \pm 0.14 \mathrm{a}$ & $0.00 \pm 0.00$ \\
0 & 0 & 0 & $0.67 \pm 0.34 \mathrm{a}$ & $0.15 \pm 0.01$ \\
\hline
\end{tabular}

Before attracticide applications there were no significant differences in male captures in this orchard, $\mathrm{F}=0.35 ; \mathrm{df}=8.16 ; \mathrm{p}>0.25$. No ANOVA was conducted after applications.

it is more likely that disruption or point source competition is the main factor reducing the approach of males to traps. If so, the addition of an insecticide into the attracticide formulation may not be necessary.

Trap captures tended to be lower when greater pheromone concentrations and higher source densities were used. In fact, there were significantly greater captures when both the lowest source density and the lowest pheromone concentration were used (Tables 2 and 4). Miller et al. (1990) observed a similar effect and proposed this was due either to male removal by toxic contact with the attracticide source or the disruption or competition effect. 
Table 4. Captures of Choristoneura rosaceana between Aug. 28-Sep. 4 (period pre-treatments) and between Sep. 8Oct. 11 (post-treatments) in apple orchard plots treated with different attracticide source densities (750 vs. 2,250 droplets $\left.\mathrm{ha}^{-1}\right)$, with $6 \%$ permethrin, using two pheromone concentrations at the source $(1.6$ or $16 \%)$, Quincy, Washington, USA.

Cuadro 4. Capturas (machos/trampa/día) de Choristoneura rosaceana entre el 28 de agosto y el 4 de septiembre (pretratamientos) y entre el 08 de septiembre y el 11 de octubre (postratamientos) en un huerto de manzanos tratado con diferentes densidades de fuentes atracticidas ( $750 \mathrm{vs.} 2.250$ gotas ha $\left.{ }^{-1}\right)$, con permetrina (6\%), usando dos concentraciones de feromona en la fuente (1,6 ó 16\%), Quincy, Washington, EE.UU.

\begin{tabular}{cccccc}
\hline $\begin{array}{c}\text { Pheromone } \\
(\%)\end{array}$ & $\begin{array}{c}\text { Permethrin } \\
(\%)\end{array}$ & $\begin{array}{c}\text { Source density } \\
\text { (droplets ha }^{-\mathbf{~}} \text { ) }\end{array}$ & & \multicolumn{2}{c}{ Average males/trap/day \pm SEM } \\
\hline 1.6 & 6 & 750 & $0.48 \pm 0.27 \mathrm{a}$ & $0.02 \pm 0.02 \mathrm{~b}$ \\
1.6 & 6 & 2,250 & $0.43 \pm 0.17 \mathrm{a}$ & $0.00 \pm 0.00 \mathrm{c}$ \\
16 & 6 & 750 & $0.33 \pm 0.13 \mathrm{a}$ & $0.00 \pm 0.00 \mathrm{c}$ \\
16 & 6 & 2,250 & $0.38 \pm 0.21 \mathrm{a}$ & $0.00 \pm 0.00 \mathrm{c}$ \\
0 & 0 & 0 & $0.33 \pm 0.33 \mathrm{a}$ & $0.12 \pm 0.15 \mathrm{a}$ \\
\hline
\end{tabular}

Before attracticide applications there were no significant differences in male captures in this orchard, $\mathrm{F}=0.15 ; \mathrm{df}=4.12 ; \mathrm{p}>0.25$. However, after treatments, significant differences were observed, $\mathrm{F}=59$; $\mathrm{df}=4.12 ; \mathrm{p}<0.001$.

Table 5. Captures of Pandemis pyrusana between Aug. 23-27 (period pre-treatments) and Aug. 28-Oct. 3 (post-treatments) in apple orchard plots treated with different attracticide source densities $(1,000 \mathrm{vs.} \mathrm{3,000} \mathrm{droplets} \mathrm{ha-1),} \mathrm{with} \mathrm{permethrin}$ $(6 \%)$ using two pheromone concentrations at the source (1.6 or 16\%), Quincy, Washington, USA.

Cuadro 5. Capturas de Pandemis pyrusana entre el 23-27 de agosto (pretratamientos) y entre 28 de agosto-3 de octubre (postratamientos) en un huerto de manzanos tratado con diferentes densidades de fuentes atracticidas $\left(1.000\right.$ vs. 3.000 gotas ha $\left.^{-1}\right)$, con permetrina (6\%), usando dos concentraciones de feromona en la fuente (1,6 ó $16 \%)$, Quincy, Washington, EE.UU.

\begin{tabular}{ccccc}
\hline $\begin{array}{c}\text { Pheromone } \\
(\%)\end{array}$ & $\begin{array}{c}\text { Permethrin } \\
(\%)\end{array}$ & $\begin{array}{c}\text { Source density } \\
\text { (droplets ha }^{-1} \text { ) }\end{array}$ & & \multicolumn{2}{c}{ Average males/trap/day \pm SEM } \\
\hline 1.6 & 6 & 1,000 & $0.42 \pm 0.17 \mathrm{a}$ & $0.02 \pm 0.02 \mathrm{~b}$ \\
1.6 & 6 & 3,000 & $0.50 \pm 0.38 \mathrm{a}$ & $0.00 \pm 0.00 \mathrm{~b}$ \\
16 & 6 & 1,000 & $0.33 \pm 0.33 \mathrm{a}$ & $0.02 \pm 0.02 \mathrm{~b}$ \\
16 & 6 & 3,000 & $0.33 \pm 0.17 \mathrm{a}$ & $0.00 \pm 0.00 \mathrm{~b}$ \\
0 & 0 & 0 & $0.42 \pm 0.30 \mathrm{a}$ & $0.19 \pm 0.09 \mathrm{a}$ \\
\hline
\end{tabular}

Before attracticide applications there were no significant differences in male captures in this orchard, $\mathrm{F}=0.7 ; \mathrm{df}=4.12 ; \mathrm{p}>0.25$. However, after treatments, significant differences were observed, $\mathrm{F}=18.47$; $\mathrm{df}=4.12 ; \mathrm{p}<0.001$.

Considering the reports of failures using conventional mating disruption formulations (Knight et al., 1996; Lawson et al., 1996; Nobbs et al., 1999), and assuming that this is the mechanism that better explains the effects observed in this report, the formulation (grease matrix) and densities of sources evaluated should be tested for mating disruption purposes.

In all field trials, moth captures after the treatments were applied in the field, were lower than before. This could be due to either the natural reduction in population density as a result of the onset of fall (Beers et al., 1993), or because of some effect of attracticide treatments in the whole treated area, or both. This hypothesis, however, remains unclear, and more trials with greater field populations will be needed to solve these questions regarding $C$. rosaceana and $P$. pyrusana.

\section{CONCLUSIONS}

Despite the fact that field trials were conducted under relatively homogeneous but low $C$. rosaceana and $P$. pyrusana densities, significantly less males were captured in traps when greater pheromone concentrations were used at the sources. Apparently, the addition of permethrin into the formulation did not contribute to a reduction of male populations, questioning the viability of these types of attracticides against these pests. However, the possible disruptive effect observed on males of both species opens chances to evaluate these free-insecticide formulations as disruptive treatments. 


\section{LITERATURE CITED}

Beers, E.H., J.F. Brunner, M. Willet, and G. Warner. 1993. Orchard pest management. A resource book for the Pacific Northwest. 276 p. Good Fruit Grower, Yakima, Washington, USA.

Charmillot, P.J., D. Hofer, and D. Pasquier. 2000. Attract and kill: a new method for control of the codling moth Cydia pomonella. Entomol. Exp. Appl. 94:211-216.

Curkovic, T., y J.F. Brunner. 2003. Evaluación de una formulación atracticida para control de Cydia pomonella (L.) (Lepidoptera: Tortricidae) en manzanos en el Estado de Washington, EE.UU. Agric. Téc. (Chile) 63:231-239.

Curkovic, T., and J.F. Brunner. 2005. Residual and sublethal effects of an attracticide formulation on Choristoneura rosaceana (Harris), Pandemis pyrusana Kearfott, and Cydia pomonella (L.) males (Lepidoptera: Tortricidae). Crop Prot. 24:637-641.

Curkovic, T., and J.F. Brunner. 2006. Evaluation of permethrin for attracticide development against Choristoneura rosaceana and Pandemis pyrusana (Lepidoptera: Tortricidae) males. Crop Prot. 25:973976.

Curkovic, T., J.F. Brunner, and P.J. Landolt. 2006. Courtship behavior of Choristoneura rosaceana and Pandemis pyrusana (Lepidoptera: Tortricidae). Ann. Entomol. Soc. Am. 99:617-624.

De Souza, K.R., L.J. McVeigh, and D.J. Wright. 1992. Selection of insecticides for lure and kill studies against Spodoptera littoralis (Lepidoptera: Noctuidae). J. Econ. Entomol. 85:2100-2106.

Downham, M.C., L.J. McVeigh, and G.M. Moawad. 1995. Field investigations of an attracticide control technique using the sex pheromone of the Egyptian cotton leaf worm, Spodoptera littoralis (Lepidoptera: Noctuidae). Bull. Entomol. Res. 85:463-472.

Evenden, M., and J.R. McLaughlin. 2005. Male Oriental fruit moth response to a combined pheromone-based attracticide formulation targeting both Oriental fruit moth and codling moth (Lepidoptera : Tortricidae). J. Econ. Entomol. 98:317-325.

Jones, O.T. 1998. Mating disruption. p. 314-316. In Howse, P., I. Stevens, and O. Jones (eds.) Insects pheromones and their use in pest management. Chapman and Hall, London, UK.

Knight, A.L., S. Cockfield, D. Thompson, and D. Noff. 1996. Developing mating disruption for leafrollers. Proc. Wash. State Hortic. Assoc. 92:211-212.

Krupke, C.H. 1999. Behavioral response of male codling moth (Cydia pomonella (L.)) to a semiochemicalbased attract and kill management strategy. $81 \mathrm{p}$. M.Sc. thesis. Simon Fraser University, British Columbia, Canada.
Krupke, C.H., B.D. Roitberg, and G.J. Judd. 2002. Field and laboratory responses of male codling moth (Lepidoptera: Tortricidae) to a pheromone-based attract-and-kill strategy. Environ. Entomol. 31:189197.

Lawson, D.S., W.H. Reissig, A.M. Agnello, J.P. Nyrop, and W.L. Roelofs. 1996. Interference with the matefinding communication system of the obliquebanded leafroller (Lepidoptera: Tortricidae) using synthetic sex pheromones. Environ. Entomol. 25:895-905.

Miller, E., R.T. Staten, C. Nowell, and J. Gourd. 1990. Pink bollworm (Lepidoptera: Gelechiidae): point source density and its relationship to efficacy in attracticide formulations of gossyplure. J. Econ. Entomol. 82:1321-1325.

Nobbs, C.A., J.F. Brunner, and M.D. Doerr. 1999. Integrating sprayable pheromones in apple orchards for management of leafroller populations. p. 113-114. Annual Western Orchard Pest \& Disease Management Conference $73^{\text {rd }}$, Portland, Oregon. January 6-8. Oregon State University Extension Service, Corvallis, Oregon, USA.

Reding, M.E., and D.G. Alston. 1999. Efficacy of SireneCM against codling moth in Utah. p. 51-52. Annual Western Orchard Pest \& Disease Management Conference $73^{\text {rd }}$, Portland, Oregon. January 6-8. Oregon State University Extension Service, Corvallis, Oregon, USA.

Roelofs, W.L., R.F. Lagier, and S.C. Hoyt. 1977. Sex pheromone of the moth, Pandemis pyrusana. Environ. Entomol. 6:353-354.

Stevens, I. 1998. Chemical structures and diversity of pheromones. p. 135-179. In Howse, P., I. Stevens, and O. Jones (eds.). Insects pheromones and their use in pest management. Chapman and Hall, London, UK.

Suckling, D.M., and E.G. Brockerhoff. 1999. Control of light brown apple moth (Lepidoptera: Tortricidae) using an attracticide. J. Econ. Entomol. 92:367-372.

Vakenti, J.M., A.P. Gaunce, K.N. Slessor, G.G. King, S.A. Allan, H.F. Madsen, and J.H. Borden. 1988. Sex pheromone components of the obliquebanded leafroller, Choristoneura rosaceana, in the Okanagan Valley of British Columbia. J. Chem. Ecol. 14:605621.

Zar, J. 1996. Biostatistical analysis. 620 p. Prentice-Hall, Upper Saddle River, New Jersey, USA. 